\title{
Meningkatkan kemampuan berpikir kritis pada perkuliahan geometri bilangan kompleks dengan discovery learning dipadukan dengan cooperative learning tipe Number Head Together (NHT)
}

\author{
Muhammad Turmuzi ${ }^{1 *}$, Ketut Sarjana ${ }^{1}$, Junaidi $^{1}$ \\ ${ }^{1}$ Pendidikan Matematika, FKIP, Universitas Mataram, Mataram \\ tur.muzi@yahoo.co.id
}

\begin{abstract}
The purpose of this study is to improve students' critical thinking skills in Geometry lectures through discovery learning combined with NHT Type Cooperative Learning. This research uses a class action research approach. Each cycle consists of several stages, namely: planning, action, observation, and reflection. At the planning stage consists of learning plan preparation activities, the preparation of research instruments, at the action stage includes the activities of providing action in the form of learning in accordance with the learning design that has been formed in accordance with the principles of discovery learning combined with NHT Cooperative Learning Type, the observation stage includes observation activities on student activities during learning, especially during discussions and the implementation of actions and obstacles encountered, and the reflection stage is a reflection of the implementation of learning activities based on observations and results of critical thinking skills through insertion tests. Matters of concern at this stage of reflection are the assessment of the implementation of actions, the obstacles that arise, and the progress that has been achieved. To obtain research data two types of research instruments were used. The research instrument in question is the observation sheet of the implementation of learning and observation guidelines as well as test questions on critical thinking skills at the end of the cycle. The results of this study indicate that the average percentage of students' critical thinking skills increased from cycle I to cycle II, namely $62.25 \%$ in cycle I increased to $81.70 \%$ in cycle II.
\end{abstract}

Keywords: critical thinking; discovery learning; NHT.

\begin{abstract}
Abstrak
Tujuan penelitian ini adalah untuk meningkatkan kemampuan berpikir kritis mahasiswa pada perkuliahan Geometri melalui discovery learning dipadukan dengan cooperative Learning Tipe NHT. Penelitian ini menggunakan pendekatan penelitian tindakan kelas. Setiap siklus terdiri dari beberapa tahapan, yaitu: perencanaan, tindakan, observasi, dan refleksi. Pada tahap perencanaan terdiri dari kegiatan penyusunan rencana pembelajaran, penyusunan instrumen penelitian, pada tahap tindakan meliputi kegiatan pemberian tindakan berupa pembelajaran sesuai dengan rancangan pembelajaran yang telah dibentuk sesuai dengan prinsip-prinsip pembelajaran discovery learning dipadukan dengan Cooperative Learning Tipe NHT, tahap observasi meliputi kegiarn observasi terhadap aktivitas mahasiwa selama pembelajaran, khususnya pada saat diskusi dan keterlaksanaan tindakan serta hambatan-hambatan yang ditemui, dan tahap refleksi merupakan kegiatan refleksi terhadap pelaksanaan pembelajaran berdasarkan hasil observasi dan hasil penilain kemampuan berpikir kritis melalui ujian sisipan. Hal-hal yang menjadi perhatian pada tahap refleksi ini adalah penilaian terhadap keterlaksanaan tindakan, hambatan-hambatan yang muncul, serta kemajuan-kemajuan yang
\end{abstract}


telah dicapai. Untuk memperoleh data penelitian digunakan dua jenis instrumen penelitian. Instrumen penelitian yang dimaksud adalah lembar observasi pelaksanaan pembelajaran dan pedoman observasi serta soal tes kemampuan Berpikir kritis di akhir siklus. Hasil penelitian ini menunjukkan bahwa rata-rata persentase kemampuan berpikir kritis mahasiswa meningkat dari siklus I ke siklus II, yaitu 62,25 \% pada siklus I meningkat menjadi $81,70 \%$ pada siklus II.

Kata Kunci: berpikir kritis; discovery learning; NHT.

\section{PENDAHULUAN}

Perkembangan ilmu pengetahuan dan teknologi yang begitu cepat menuntut lulusan untuk mampu menguasainya agar mempunyai daya saing. Pendidikan merupakan salah satu faktor yang sangat penting dalam berperan mewujudkan manusia yang berkualitas sehingga mampu menghadapi perkembangan IPTEK. Pendidikan saat ini tidak hanya ditekankan pada aspek kognitif melainkan juga aspek non kognitif. Salah satu aspek non kognitif yang penting dikuasai saat ini adalah kemampuan berpikir kritis. Berpikir kritis meliputi kemampuan menganalisis suatu masalah, berpikir terbuka, jelas, dan berdasarkan fakta. Individu yang berpikir kritis mampu memberi alasan atas pilihan keputusan yang diambil dan terbuka terhadap perbedaan keputusan dan pendapat orang lain serta mampu mengenali alasan-alasan mengapa orang lain memiliki pendapat dan keputusan yang berbeda.

Pengembangan kemampuan berpikir kritis dalam perkuliahaan sering luput dari perhatian. Pengembangan berpikir kritis hanya diharapkan muncul sebagai dampak pengiring pembelajaran. Masih adanya kesulitan bagaimana cara mengembangkan kemampuan berpikir kritis dalam perkuliaahan sehingga pengembangan kemampuan ini kurang mendapat perhatian. Program pengembangan aspek non kognitif di luar proses perkuliahan bagi mahasiswa masih jarang, padahal kemampuan ini sangat penting untuk dimiliki. Mengingat hal tersebut, pentingnya mengembangkan pembelajaran yang dapat mengembangkan kemampuan berpikir kritis harus segera diupayakan. Model discovery learning dipadukan model pembelajaran kooperatif merupakan salah satu model yang dapat diterapkan dalam upaya meningkatkan kemampuan akademik dan soft skill khususnya kemampuan berpikir kritis mahasiswa. Ada berbagai tipe pembelajaran kooperatif. Salah satu model pembelajaran yang dapat diharapkan mampu meningkatkan kemampuan berpikir kritis dalam pembelajaran matematika adalah model pembelajaran kooperatif tipe NHT (Numbered Head Together).

Dengan setting perkuliahan model ini, mahasiswa dapat melatih kemampuan untuk membuat strategi pemecahan masalah dan menarik kesimpulan. Hal tersebut merupakan salah satu indikator kemampuan berpikir kritis. Dengan discovery learning mahasiswa dapat melatih kemampuan untuk menganalisis dan mensintesis yang merupakan salah satu indikator kemampuan berpikir kritis.

Matematika merupakan salah satu ilmu yang mempunyai peranan penting dalam pembentukan keterampilan berpikir kritis, sistematis, logis dan kreatif serta mampu 
bekerja sama, kemudian diharapkan yang memiliki keterampilan berpikir seperti ini mampu menghadapi tantangan kehidupan secara mandiri. Mata kuliah Geometri Bilangan Kompleks merupakan salah satu mata kuliah inti di Program Studi Pendidikan Matematika FKIP Universitas Mataram. Materi dalam matakuliah ini diantaranya meliputi pengertian bilangan kompleks, operasi aljabar bilangan kompleks, konjugate, modulus (nilai mutlak), bidang kartesius, bidang vektor, koordinat kutub, formula euler, dalil De Moivre dan region di bidang kompleks.

Mengingat pentingnya melatihkan kemampuan berpikir kritis, selama perkuliahan hendaknya diarahkan untuk dapat mengembangkan keterampilan tersebut. Mahasiswa yang memiliki kemampuan berpikir yang baik, maka baik pula kemampuannya dalam menyusun strategi dan taktik agar dapat meraih kesuksesan dalam persaingan global di masa depan. Melalui berpikir kritis, mahasiswa diajak berperan serta secara aktif dan efektif untuk membangun pengetahuannya sendiri. Berpikir kritis dapat dikembangkan dengan memperkaya pengalaman mahasiswa yang bermakna. Pengalaman tersebut dapat berupa kesempatan berpendapat secara lisan maupun tulisan.

Berdasarkan latar belakang di atas maka dilakukan penelitian berupa meningkatan kemampuan berpikir kritis mahasiswa pada perkuliahan Geometri Bilangan Kompleks melalui discovery learning dipadukan dengan cooperative Learning Tipe NHT.

\section{TINJAUAN PUSTAKA}

\subsection{Cooperative Learning tipe NHT}

Pembelajaran kooperatif tipe NHT merupakan salah satu tipe pembelajaran kooperatif yang menekankan pada struktur-struktur khusus yang dirancang untuk mempengaruhi pola-pola interaksi mahasiswa dalam memiliki tujuan untuk meningkatkan penguasaan isi akademik. Tipe ini dikembangkan oleh Kagen dalam Ibrahim (2000:28) dengan melibatkan para mahasiswa dalam menelaah bahan yang tercakup dalam suatu pelajaran dan mengecek pemahaman mereka terhadap isi pelajaran tersebut.

Penerapan pembelajaran kooperatif tipe NHT merujuk pada konsep Spencer Kagen dalam Ibrahim (2000 : 28) untuk melibatkan lebih banyak mahasiswa dalam menelaah materi yang tercakup dalam suatu pelajaran dengan mengecek pemahaman mereka mengenai isi pelajaran tersebut. Sebagai pengganti pertanyaan lansung kepada seluruh kelas, dosen menggunakan empat langkah sebagai berikut : (a) Penomoran, (b) Pengajuan pertanyaan, (c) Berpikir bersama, (d) Pemberian jawaban.

Langkah-langkah tersebut kemudian dikembangkan menjadi enam langkah sesuai dengan kebutuhan pelaksanaan penelitian ini. Keenam langkah tersebut adalah sebagai berikut:

\section{Langkah 1. Persiapan}


Dalam tahap ini dosen mempersiapkan rancangan pelajaran dengan membuat Rencana Tatap Muka Pembelajaran (RTM), Rancangan Tugas Mahasiswa, yang sesuai dengan model pembelajaran kooperatif tipe NHT.

\section{Langkah 2. Pembentukan Kelompok}

Dalam pembentukan kelompok disesuaikan dengan model pembelajaran kooperatif tipe NHT. Dosen membagi mahasiswa menjadi beberapa kelompok yang beranggotakan 4 sampai 5 orang mahasiswa. Dosen memberi nomor kepada setiap mahasiswa dalam kelompok dan nama kelompok yang berbeda.

\section{Langkah 3. Diskusi Masalah}

Dalam kerja kelompok, dosen membagikan Rancangan Tugas Mahasiswa (RTM) kepada setiap mahasiswa sebagai bahan yang akan dipelajari. Dalam kerja kelompok, setiap mahasiswa berpikir bersama untuk menggambarkan dan meyakinkan bahwa setiap orang mengetahui jawaban dari pertanyaan yang telah ada dalam RTM atau pertanyaan yang telah diberikan oleh dosen. Pertanyaan dapat bervariasi, dari spesifik sampai yang bersifat umum.

\section{Langkah 4. Memanggil Nomor Anggota atau Pemberian Jawaban}

Dalam tahap ini, dosen menyebut satu nomor dan para mahasiswa dari tiap kelompok dengan nomor yang sama mengangkat tangan dan menyiapkan jawaban kepada mahasiswa di kelas.

\section{Langkah 5. Memberi Kesimpulan}

Dosen memberikan kesimpulan atau jawaban akhir dari semua pertanyaan yang berhubungan dengan materi yang disajikan.

\section{Langkah 6. Memberikan Penghargaan}

Pada tahap ini, dosen memberikan penghargaan berupa kata-kata pujian pada mahasiswa dan memberi nilai yang lebih tinggi kepada kelompok yang hasil belajarnya lebih baik.

\subsection{Discovery Learning}

Metode Discovery Learning adalah teori belajar yang didefinisikan sebagai proses pembelajaran yang terjadi bila pelajar tidak disajikan dengan pelajaran dalam bentuk finalnya, tetapi diharapkan mengorganisasi sendiri. Sebagaimana pendapat Bruner, bahwa: "Discovery Learning can be defined as the learning that takes place when the student is not presented with subject matter in the final form, but rather is required to organize it him self' (Lefancois dalam Emetembun, 1986:103). Dasar ide Bruner ialah pendapat dari Piaget yang menyatakan bahwa anak harus berperan aktif dalam belajar di kelas.

Menurut Syah (2004:244) dalam mengaplikasikan metode Discovery Learning di kelas, ada beberapa prosedur yang harus dilaksanakan dalam kegiatan belajar mengajar secara umum sebagai berikut:

\section{a. Stimulation (Stimulasi/Pemberian Rangsangan)}

Stimulasi pada tahap ini berfungsi untuk menyediakan kondisi interaksi belajar yang dapat mengembangkan dan membantu mahasiswa dalam mengeksplorasi bahan. 
Dalam hal ini Bruner memberikan stimulation dengan menggunakan teknik bertanya yaitu dengan mengajukan pertanyaan-pertanyaan yang dapat menghadapkan mahasiswa pada kondisi internal yang mendorong eksplorasi. b. Problem Statement (Pernyataan/ Identifikasi Masalah)

Setelah dilakukan stimulasi langkah selanjutya adalah dosen memberi kesempatan kepada mahasiswa untuk mengidentifikasi sebanyak mungkin agenda-agenda masalah yang relevan dengan bahan pelajaran, kemudian salah satunya dipilih dan dirumuskan dalam bentuk hipotesis (jawaban sementara atas pertanyaan masalah) (Syah 2004:244).

\section{c. Data Collection (Pengumpulan Data)}

Ketika eksplorasi berlangsung dosen juga memberi kesempatan kepada para mahasiswa untuk mengumpulkan informasi sebanyak-banyaknya yang relevan untuk membuktikan benar atau tidaknya hipotesis (Syah, 2004:244). Pada tahap ini berfungsi untuk menjawab pertanyaan atau membuktikan benar tidaknya hipotesis.

\section{d. Data Processing (Pengolahan Data)}

Menurut Syah (2004:244) pengolahan data merupakan kegiatan mengolah data dan informasi yang telah diperoleh para mahasiswa baik melalui wawancara, observasi, dan sebagainya, lalu ditafsirkan.

\section{e. Verification (Pembuktian)}

Pada tahap ini mahasiswa melakukan pemeriksaan secara cermat untuk membuktikan benar atau tidaknya hipotesis yang ditetapkan tadi dengan temuan alternatif, dihubungkan dengan hasil data processing (Syah, 2004:244).

\section{f. Generalization (Menarik Kesimpulan/Generalisasi)}

Tahap generalisasi/ menarik kesimpulan adalah proses menarik sebuah kesimpulan yang dapat dijadikan prinsip umum dan berlaku untuk semua kejadian atau masalah yang sama, dengan memperhatikan hasil verifikasi (Syah, 2004:244). Berdasarkan hasil verifikasi maka dirumuskan prinsip-prinsip yang mendasari generalisasi.

\subsection{Berpikir Kritis}

Definisi berpikir kritis telah dipresentasikan dengan berbagai cara. Beyer (1995) menawarkan definisi yang paling sederhana: "Berpikir kritis berarti membuat penilaian- penilaian yang masuk akal". Beyer memandang berpikir kritis sebagai menggunakan kriteria untuk menilai kualitas sesuatu, dari kegiatan yang paling sederhana seperti kegiatan normal sehari-hari sampai konklusi.

Angelo mengidentifikasi lima perilaku yang sistematis dalam berpikir kritis. Penilaku tersebut dapat digambarkan sebagai berikut:

a. Keterampilan Menganalisis, merupakan suatu keterampilan menguraikan sebuah struktur ke dalam komponen-komponen agar mengetahui pengorganisasian struktur tersebut (http://www.uwsp/cognitif.htm.). Kata-kata operasional yang mengindikasikan keterampilan berpikir analitis, diantaranya: menguraikan, membuat diagram, mengidentifikasi, menggambarkan, menghubungkan, memerinci, dan sebagainya. 
b. Keterampilan Mensintesis, merupakan keterampilan yang berlawanan dengan keterampilan menganalisis. Keterampilan mensintesis adalah keterampilan menggabungkan bagian-bagian menjadi sebuah bentukan atau susunan yang baru. Pertanyaan sintesis menuntut pembaca untuk menyatupadukan semua informasi yang diperoleh dari materi bacaannya, sehingga dapat menciptakan ideide baru yang tidak dinyatakan secara eksplisit di dalam bacaannya. Pertanyaan sintesis ini memberi kesempatan untuk berpikir bebas terkontrol (Harjasujana, 1987: 44).

c. Keterampilan Mengenal dan Memecahkan Masalah. Keterampilan ini merupakan keterampilan aplikatif konsep kepada beberapa pengertian baru. Keterampilan ini menuntut pembaca untuk memahami bacaan dengan kritis sehinga setelah kegiatan membaca selesai mahasiswa mampu menangkap beberapa pikiran pokok bacaan, sehingga mampu mempola sebuah konsep. Tujuan keterampilan ini bertujuan agar pembaca mampu memahami dan menerapkan konsep-konsep ke dalam permasalahan atau ruang lingkup baru (Walker, 2001:15).

d. Keterampilan Menyimpulkan, yaitu kegiatan akal pikiran manusia berdasarkan pengertian/pengetahuan (kebenaran) yang dimilikinya, dapat beranjak mencapai pengertian/pengetahuan (kebenaran) yang baru yang lain (Salam, 1988: 68). Berdasarkan pendapat tersebut dapat dipahami bahwa keterampilan ini menuntut pembaca untuk mampu menguraikan dan memahami berbagai aspek secara bertahap agar sampai kepada suatu formula baru yaitu sebuah simpulan. Proses pemikiran manusia itu sendiri, dapat menempuh dua cara, yaitu : deduksi dan induksi. Jadi, kesimpulan merupakan sebuah proses berpikir yang memberdayakan pengetahuannya sedemikian rupa untuk menghasilkan sebuah pemikiran atau pengetahuan yang baru.

e. Keterampilan Mengevaluasi atau Menilai. Keterampilan ini menuntut pemikiran yang matang dalam menentukan nilai sesuatu dengan berbagai kriteria yang ada. Keterampilan menilai menghendaki pembaca agar memberikan penilaian tentang nilai yang diukur dengan menggunakan standar tertentu (Harjasujana, 1987: 44).

\section{METODE PELAKSANAAN}

\subsection{Pendekatan Penelitian}

Penelitian ini menggunakan pendekatan penelitian tindakan kelas. Setiap siklus terdiri dari beberapa tahapan, yaitu: perencanaan, tindakan, observasi, dan refleksi. Penelitian ini dilakukan di Program Studi Pendidikan Matematika FKIP Universitas Mataram pada semester genap tahun akademik 2015/2016. Subjek penelitian ini adalah mahasiswa Program Studi Pendidikan Matematika pada semester genap tahun akademik 2015/2016 menempuh mata kuliah Geometri Bilangan Kompleks sebanyak 30 mahasiswa. Obyek penelitian meliputi seluruh proses pembelajaran. 


\subsection{Prosedur Penelitian}

\section{Siklus I}

\section{a. Perencanaan}

Kegiatan pada tahap ini meliputi penyusunan rencana pembelajaran, penyusunan instrumen penelitian, pembentukan kelompok terdiri atas 4 orang.

\section{b. Tindakan}

Tindakan berupa pembelajaran sesuai dengan rancangan pembelajaran yang telah dibentuk sesuai dengan prinsip-prinsip pembelajaran discovery learning dipadukan dengan Cooperative Learning Tipe NHT.

\section{c. Observasi}

Selama kegiatan pembelajaran dilakukan observasi terhadap aktivitas mahasiwa selama pembelajaran, khususnya pada saat diskusi dan keterlaksanaan tindakan serta hambatan-hambatan yang ditemui. Untuk mengetahui pencapaian tujuan yang direncanakan yaitu peningkatan kemampuan berpikir kritis dan hasil belajar mahasiswa dilakukan evaluasi terhadap kemampuan berpikir kritis mahasiswa melalui soal tes.

\section{d. Refleksi}

Pada akhir siklus dilakukan refleksi terhadap pelaksanaan pembelajaran berdasarkan hasil observasi dan hasil penilain kemampuan berpikir kritis melalui ujian sisipan. Hal-hal yang menjadi perhatian pada tahap refleksi ini adalah penilaian terhadap keterlaksanaan tindakan, hambatan-hambatan yang muncul, serta kemajuan-kemajuan yang telah dicapai, yang meliputi 5 aspek kemampuan berpikir kritis dan hasil belajar (ujian) mahasiswa. Perencanaan untuk tindakan berikutnya disusun berdasarkan hasil refleksi.

\section{Siklus II}

Tahapan-tahapan yang dilakukan pada siklus I diulangi pada siklus II, dengan beberapa perbaikan berdasarkan hasil refleksi pada siklus I. Beberapa aspek yang menjadi indikator keberhasilan proses pembelajaran adalah meningkatnya kemampuan berpikir kritis yaitu pada setiap aspek pada kategori tinggi dan rata-rata kemampuan berpikir kritis pada kategori tinggi.

\subsection{Instrumen Penelitian}

Untuk memperoleh data penelitian digunakan dua jenis instrumen penelitian. Instrumen penelitian yang dimaksud adalah lembar observasi pelaksanaan pembelajaran dan pedoman observasi serta soal tes kemampuan berpikir kritis di akhir siklus.

\subsection{Analisis Data}

Data penelitian diperolah dari hasil observasi yang dilakukan selama pembelajaran berlangsung dan tes. Analisis data yang digunakan adalah kuantitatif dan kualitatif. Teknik kualitatif digunakan untuk mendeskripsikan keterlaksanaan rencana tindakan, 
menggambarkan hambatan-hambatan yang muncul dalam pelaksanaan pembelajaran dan mendeskripsikan aktivitas/partisipasi mahasiswa dalam kegiatan pembelajaran, dan kemampuan berpikir kritis berdasarkan hasil pengamatan. Sedangkan analisis kuantitatif digunakan untuk mendeskripsikan tentang efektivitas dari pembelajaran yang meliputi hasil belajar dan kemampuan berpikir kritis mahasiswa.

\section{HASIL DAN PEMBAHASAN}

Penelitian ini dilaksanakan dalam dua siklus. Siklus pertama dalam penelitian ini dengan empat tahapan yaitu perencanaan, tindakan, observasi, dan refleksi. Pada tahap perencanaan yaitu dilakukan dengan merancang pembelajaran yang akan dilakukan dan menyiapkan instrumen penelitian. Perancangan pembelajaran meliputi rencana pembelajaran dengan materi Geometri pada Bidang Kompleks dengan menggunakan model penemuan terbimbing dipadukan dengan metode NHT. Adapun langkah-langkah dari pembelajaran ini adalah:

a. Numbering, pada saat numbering dilakukan pembagian kelompok, masing-masing kelompok beranggota 4 orang yang heterogen dan diberi nomer.

b. Questioning, Setelah mahasiswa berkelompok, kemudian dosen memberikan suatu permasalahan. Secara individual mahasiswa diminta untuk mencari penyelesaian dengan caranya masing-masing. Mahasiswa diminta untuk menemukan penyelesaian dengan berbagai cara (inquiry). Mahasiswa diminta untuk menemukan jawaban dari permasalahan yang diberikan dosen, apabila mahasiswa terlihat menemukan kesulitan diminta untuk bertanya dan dosen memberi pengarahan berupa pertanyaan-pertanyaan pembantu.

c. Head together, para mahasiswa berdiskusi dengan kelompoknya dan mendiskusikan hasil penemuannya untuk mencari penyelesaian. Apabila masih ada kesulitan, dengan indikasi pada saat observasi terlihat masih ada kelompok yang belum menemukan jawaban, dosen memberi tambahan pertanyaan yang terstruktur yang membimbing mahasiswa (guided).

d. Answering, pada langkah ini dosen menyebutkan salah satu nomer, dan mahasiswa dengan nomer tersebut bertanggung jawab untuk membahas permasalahan, dan mahasiswa yang lain ikut berpendapat.

Observasi dilakukan selama proses pembelajaran dengan menggunakan lembar observasi untuk mengamati apakah jalannya pembelajaran sesuai dengan yang di rencanakan dan untuk mencatat kesulitan kesulitan pembelajaran untuk diperbaiki. Refleksi dilakukan setelah pembelajaran. Dari siklus pertama tidak ditemukan kendala yang berarti hanya saja waktu untuk berdiskusi dan membahas diskusi yang masih kurang yang akan diperbaiki pada siklus II.

Pada siklus kedua secara umum langkah-langkah penelitian sama dengan siklus pertama. Adapun hasil dari observasi keterlaksanaan pembelajaran seperti Tabel 1 di bawah ini. 
Tabel 1. Hasil Observasi Keterlaksanaan Pembelajaran

\begin{tabular}{|c|c|c|c|}
\hline No & Indikator & Skor Siklus I & Skor Siklus II \\
\hline 1 & Aktivitas dosen dalam kegiatan Pendahuluan & 3 & 2 \\
\hline 2 & $\begin{array}{l}\text { Pemberian rangsangan dengan merumuskan } \\
\text { masalah (stimulation) }\end{array}$ & 2 & 3 \\
\hline 3 & $\begin{array}{l}\text { Membimbing mahasiswa saat } \\
\text { mengidentifikasi masalah ( Problem } \\
\text { statement) }\end{array}$ & 2 & 2 \\
\hline 4 & $\begin{array}{l}\text { Memberikan arahan kepada mahasiswa saat } \\
\text { berdiskusi kelompok (data collection, data } \\
\text { processing). }\end{array}$ & 3 & 3 \\
\hline 5 & $\begin{array}{l}\text { Memberikan kesempatan kepada mahasiswa } \\
\text { untuk mempresentasikan hasil disklusi } \\
\text { kelompok (verification, generalization). }\end{array}$ & 3 & 3 \\
\hline 6 & Kegiatan Penutup Pembelajaran & 3 & 3 \\
\hline & Jumlah skor seluruh indikator & 16 & 16 \\
\hline & Kategori & Sangat Baik & Sangat Baik \\
\hline
\end{tabular}

Melalui tahapan-tahapan dalam pembelajaran dengan model penemuan terbimbing dipadukan dengan metode NHT, dapat memfasilitasi mahasiswa untuk mengasah kemampuan mensintesis. Pada saat numbering, mahasiswa mendapatkan nomor yang berbeda-beda pada masing-masing kelompok. Hal ini menanamkan rasa tanggung jawab terhadap kelompoknya, sehingga mahasiswa akan berupaya semaksimal mungkin untuk menyumbangkan idenya. Pada saat Questioning, mahasiswa dilatih untuk menganalisis permasalahan, mengkaitkan dengan suatu konsep dalam rangka menemukan penyelesaian. Mahasiswa dilatih untuk menemukan penyelesaian dari permasalahan. Pada langkah ini mahasiswa juga belajar mensintesis. 


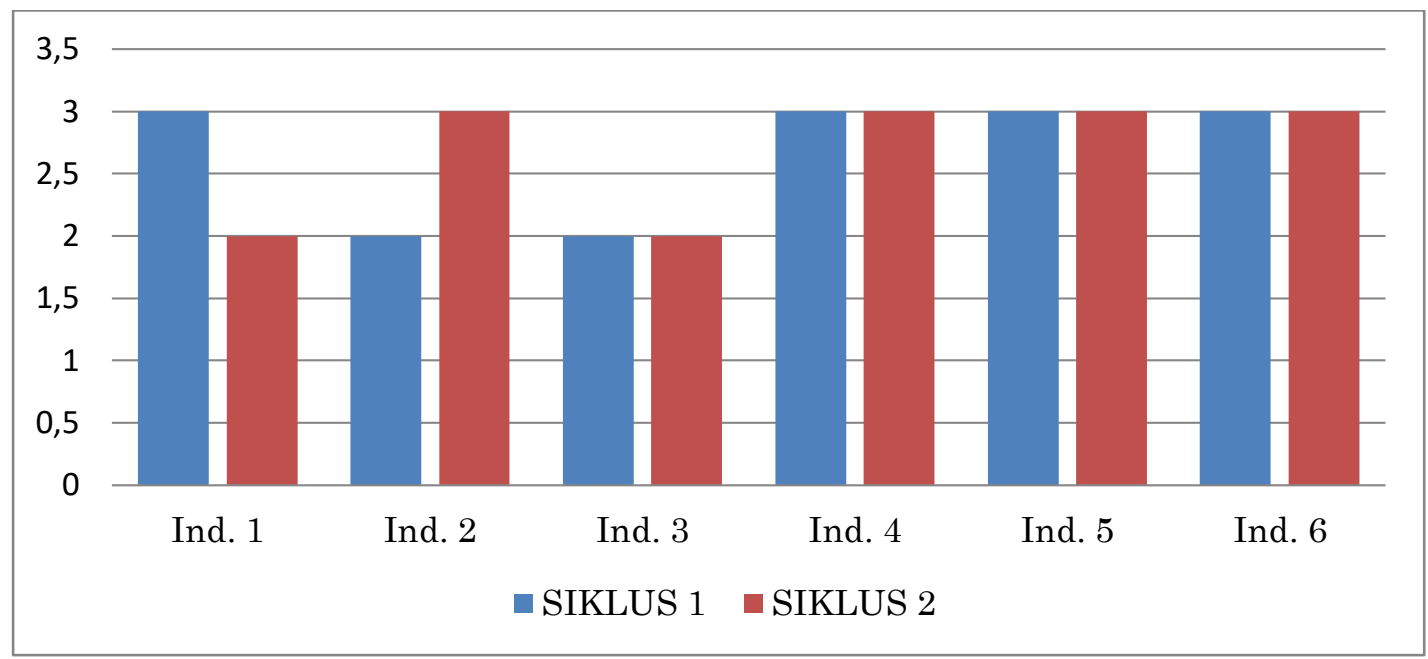

Keterangan: Ind. = Indikator

Gambar 1. Observasi Keterlaksanaan Pembelajaran Siklus 1 dan 2

Aspek-aspek berpikir kritis dalam penelitian ini meliputi kemampuan menganalisis, kemampuan mensintesis, kemampuan merancang pemecahan masalah, kemampuan menarik kesimpulan, dan kemampuan mengevaluasi. Hasil kemampuan tersebut pada tiap-tiap siklus seperti Tabel 2 di bawah ini.

Tabel 2. Hasil Kemampuan pada Aspek Berpikir Kritis

\begin{tabular}{llcc}
\hline No & \multicolumn{1}{c}{ Aspek Berpikir Kritis } & Siklus 1 (\%) & Siklus 2(\%) \\
\hline 1 & Kemampuan Menganalisi & 61,75 & 84,50 \\
2 & Kemampuan Mensintesis & 64,25 & 82,25 \\
3 & Kemampuan Merumuskan Penyelesaian & 63,50 & 81,00 \\
4 & Kemampuan Menarik Kesimpulan & 57,75 & 79,50 \\
5 & Kemampuan Mengevaluasi & 64,00 & 81,25 \\
& Rata-Rata (\%) & 62,25 & 81,70 \\
\hline
\end{tabular}

Berdasarkan tabel lembar observasi di atas bahwa ketercapaian pembelajaran aktivitas mahasiswa adalah sangat aktif dan keterlaksanaan pembelajaran oleh dosen berkategori sangat baik. Dan skor kemampuan berfikir kritis pada siklus ke II pada tiap-tiap aspek pada kategori tinggi dan rata-rata kemampuan berfikir kritis pada kategori tinggi. 


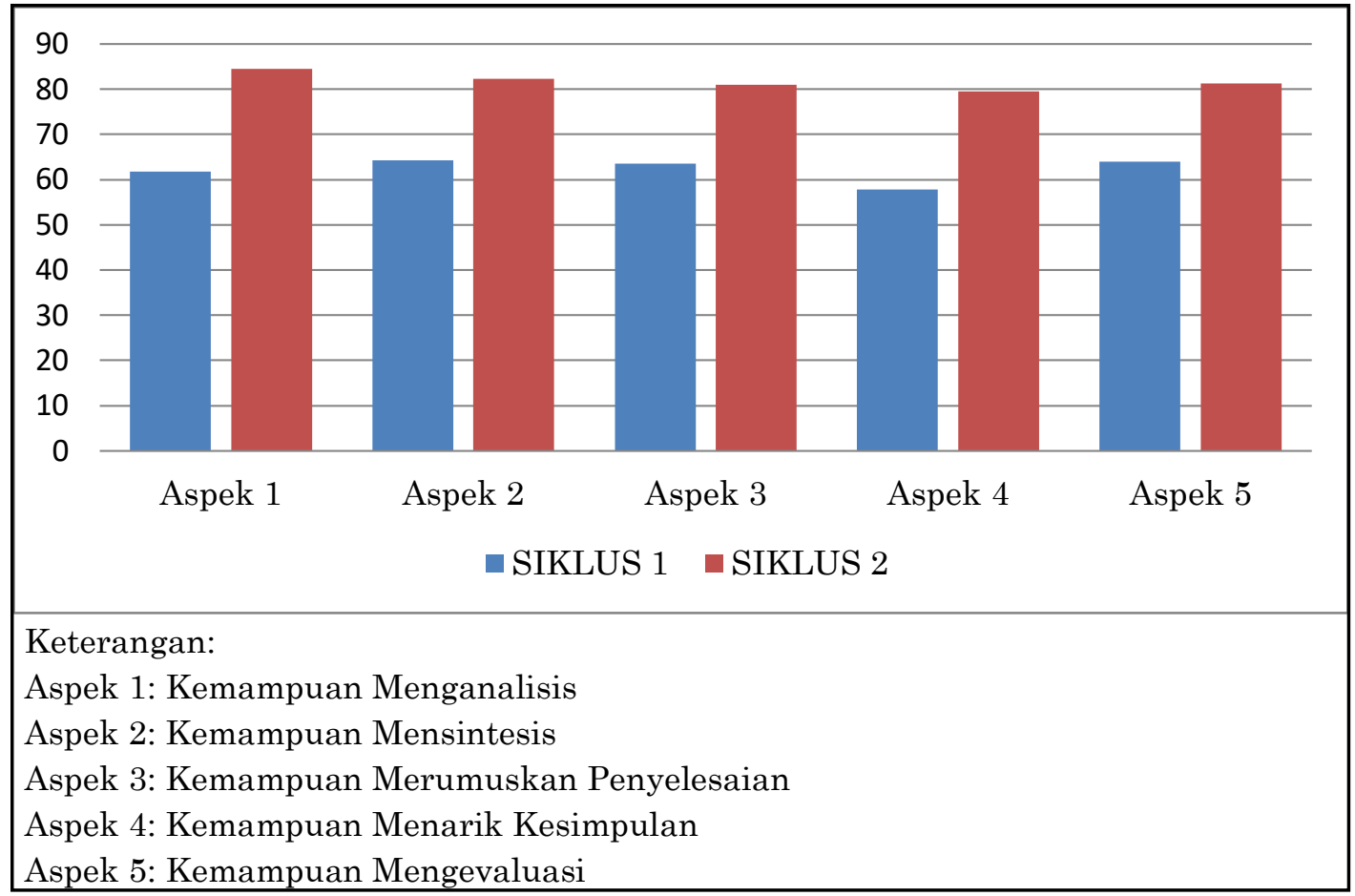

Gambar 2. Persentase Aspek Berpikir Kritis Siklus 1 dan 2

\section{SIMPULAN}

Berdasarkan hasil penelitian dan pembahasan dapat disimpulkan bahwa rata-rata persentasse kemampuan berpikir kritis mahasiswa adalah $62,25 \%$ pada siklus I meningkat menjadi $81,70 \%$ pada siklus II. Sedangkan langkah-langkah metode penemuan terbimbing dipadukan model kooperatif tipe NHT yang dapat meningkatkan kemampuan berpikir kritis adalah dengan:

A. Numbering, yaitu mahasiswa diminta membaca materi dan langsung diberikan satu soal untuk dikerjakan.

B. Questioning, yaitu pemberian masalah atau pertanyaan yang disertai dengan pembimbingan berupa pertanyaan apabila diperlukan.

C. Together, yaitu berdiskusi secara kelompok mendiskusikan penemuannya masing-masing.

D. Answering, yaitu merumuskan jawaban dari permasalahan.

Adapun saran penelitian ini adalah pembelajaran dengan model penemuan terbimbing dipadukan dengan metode NHT, dapat memfasilitasi mahasiswa untuk mengasah kemampuan berpikir kritis, oleh sebab itu model pembelajaran ini dapat dikembangkan untuk melatih berpikir krtitis pada rumpun mata kuliah lain seperti di Kalkulus, Aljabar, Analisis atau statistik.

\section{REFERENSI}

Lie, A. (2004). Cooperative Learning: Mempraktikkan Cooperative Learning di Ruang-Ruang Kelas. Jakarta: Grasindo. 
Lie, A. (2002). Cooperative Learning. Jakarta: PT Grasindo.

Achmad, A. Memahami Berpikir Kritis. http://researchengines.com/1007arief3.html diakses tanggal 16 Juni 2010

Jacobsen,D.A., Eggen, P., \& Kauchak, D. (2009). Methods for Teaching Metode-Metode Pengajaran Meningkatkan Belajar Mahasiswa TK-SMA. Edisi ke-8. Yogyakarta: Pustaka Pelajar.

Lestari, E. Telaah Kritis terhadap Clinical Reasoning dalam Konteks Critical Thinking.pdf File 24 Kemampuan Berpikir kritis dan kreatif matematik.pdf.

Ibrahim, M, dkk. 2000. Pembelajaran Kooperatif. Surabaya: Universitas Negeri Surabaya University Press.

Jurnal Geliga Sains 3 (2), 8-13, 2009 Program Studi Pendidikan Fisika FKIP Universitas Riau ISSN 1978-502X.

Sudjana, N. (2002). Penilaian Hasil Belajar Mengajar. Bandung: PT Remaja Rosdakarya.

Slavin, R.E. (2009). Cooperative Learning Teori Riset dan Praktik. Bandung: Nusa Media.

Syah, M. (1996). Psikologi Pendidikan Suatu Pendekatan Baru. Bandung: PT Remaja Rosdakarya 